\title{
MYCORRHIZAL EFFECTIVENESS AND MANGANESE TOXICITY IN SOYBEAN AS AFFECTED BY SOIL TYPE AND ENDOPHYTE
}

\author{
Marco Antonio Nogueira ${ }^{1}$; Elke Jurandy Bran Nogueira Cardoso $o^{2,3 *}$ \\ ${ }^{1}$ UEL - Depto. de Microbiologia, C.P. 6001 - 86051-990 - Londrina, PR - Brasil. \\ ${ }_{3}^{2}$ USP/ESALQ - Depto. de Solos e Nutrição de Plantas, C.P. 9 - 13418-900 - Piracicaba, SP - Brasil. \\ ${ }^{3} \mathrm{CNPq}$ scholar. \\ *Corresponding author <ejbncard@esalq.usp.br>
}

\begin{abstract}
Mycorrhizal plants may present Mn toxicity alleviation and this depends on the plant-endophyteenvironment interaction. The effectiveness of three arbuscular mycorrhizal fungi (AMF) (Glomus macrocarpum, G. etunicatum, G. intraradices) and a control without AMF in two soils: Typic Rhodudalf with high Mn availability and a Typic Quartzipsamment, with low Mn availability, was evaluated in a timecourse experiment at 3, 6, 9 and 12 weeks after soybean (Glycine max L.) seedling emergence. The objective was to select the most effective AMF species to enhance plant growth and to assess its effects upon Mn uptake by plants and Mn availability in the soil. For the sandy soil, AMF inoculation resulted in increased plant biomass, especially with $G$. intraradices and G. etunicatum. Lower Mn concentrations were observed in shoot and root of mycorrhizal plants. For the clayey soil, there was also an increase in plant biomass, but only for plants inoculated with $G$. intraradices and G. etunicatum. Mycorrhizal plants presented higher Mn concentrations in shoot and root and there was an increase of available $\mathrm{Mn}$ in the soil, in relation to the control, especially in the treatment with G. macrocarpum. When inoculated with G. macrocarpum, plants presented Mn toxicity symptoms and reduced biomass in comparison to control plants. The effects of mycorrhizal inoculation, either positive or negative, were most intense at 9 and 12 weeks.
\end{abstract}

Key words: Mn, availability, metal, mycorrhiza, toxicity, uptake

\section{EFICIÊNCIA MICORRÍZICA E TOXIDEZ DE MANGANÊS EM SOJA EM FUNÇÃO DO TIPO DE SOLO E DA ESPÉCIE DO ENDÓFITO}

\begin{abstract}
RESUMO: Plantas micorrizadas podem apresentar atenuação da toxidez causada pelo excesso de Mn, mas isso depende da interação planta-endófito-ambiente. Avaliou-se a eficiência de três espécies de fungos micorrízicos arbusculares (FMA) (Glomus macrocarpum, G. etunicatum, G. intraradices, e um controle sem FMA, em quatro épocas de coleta (3, 6, 9 e 12 semanas após a emergência das plântulas de soja (Glycine max L.)) num Nitossolo Vermelho eutroférrico típico, muito argiloso, com alta disponibilidade de Mn e num Neossolo Quartzarênico típico, com baixa disponibilidade de Mn. O objetivo foi avaliar a eficiência micorrízica desses FMA nesses substratos, em diversas épocas, bem como os efeitos sobre a disponibilidade de Mn no substrato e sua absorção pelas plantas. No substrato arenoso, a micorrização aumentou a biomassa das plantas, com destaque para $G$. intraradices e G. etunicatum. Nesse caso, houve menor concentração de Mn na parte aérea e raízes das plantas. No substrato argiloso, a micorrização com G. intraradices e G. etunicatum aumentou a biomassa das plantas, mas também aumentou a disponibilidade de Mn no substrato e a concentração na parte aérea e raízes em relação ao controle, com mais intensidade nas plantas com G. macrocarpum. Nesse caso, houve sintomas de toxidez de Mn e diminuição da biomassa das plantas. Os efeitos da micorrização, positivos ou negativos, foram mais expressivos com 9 e 12 semanas.

Palavras-chave: Mn, absorção, disponibilidade, metal, micorriza, toxicidade
\end{abstract}

\section{INTRODUCTION}

Mycorrhizal associations are related to several benefits to the host plant. Besides the improvement of the nutritional state, other benefits like increasing of plant resistance to pathogens, to ionic stresses such as Mn excess (Cardoso, 1985; Bethlenfalvay \& Franson, 1989) and to drought stress are also relevant. Nevertheless, depending on the interactions between the endophyte, the host and the environment, the effects may as well be negative or deleterious to the host plant (Medeiros et al., 1995; Nogueira \& Cardoso, 2000).

Although there is no known host specificity for arbuscular mycorrhizal fungi (AMF), root colonization and growth response depend on the interaction of both symbionts and they are affected by several conditions, such as soil pH (Lambais \& Cardoso, 1988), fungal species or isolate (Lambais \& Cardoso, 1990) and the stage 
of development of the host plant (Bethlenfalvay et al., 1982b). Therefore, very often one can not find a simple correlation between the percent root colonization and host growth responses (Allen, 2001).

The lack of correlation between infectivity and mycorrhizal effectiveness may be related to the time that it takes for the establishment of the symbiosis, mainly for annual crops (Abbott \& Robson, 1981). Nogueira \& Cardoso (2000) observed that Gigaspora margarita, besides presenting a slow phase of root colonization, also produced less total external mycelium compared to $G$. intraradices. This behavior probably limited plant response to mycorrhization and induced a transient plant growth depression in relation to the non-mycorrhizal control. As the plant response to mycorrhization may vary along the plant cycle, wrong interpretations may arise from short time experiments, mainly those in which the AMF presents a slow phase of root colonization, without enough time to eventually have a host growth increase (Bethlenfalvay et al., 1982b). The proportion between the external and internal mycorrhizal mycelium may also influence the symbiosis effectiveness (Abbott \& Robson, 1981). A negative response for host growth (parasitism) may be the result of great internal fungal colonization and lack of enough external growth for an effective mining of the nearby soil (Bethlenfalvay et al., 1982a).

Infectivity as well as symbiotic effectiveness for the different endophytes vary according to the plant-fungus-environment interactions, and this poses the need for selecting the most effective interaction for each condition. The aim of this work was to evaluate the effectiveness of three AMF species in promoting soybean development, and their effects on the availability and uptake of Mn by plants grown in two soils: one sandy, with low Mn availability and one clayey, with high Mn availability.

\section{MATERIAL AND METHODS}

The experiment was installed in a greenhouse with pots containing four $\mathrm{kg}$ of soil, previously autoclaved at $121^{\circ} \mathrm{C}$ for $2 \mathrm{~h}$. Treatments consisted of two soil types: sandy (0-0.2 m layer of a Typic Quartzipsamment, containing 830, 40 and $130 \mathrm{~g} \mathrm{~kg}^{-1}$ of sand, silt and clay, respectively) and clayey (0-0.2 m layer of a Typic Rhodudalf, containing 250, 150 and $600 \mathrm{~g} \mathrm{~kg}^{-1}$ of sand, silt and clay, respectively), in combination with three species of AMF (Glomus macrocarpum, G. etunicatum, G. intraradices) and a non-inoculated control, with six replicates. Plants were harvested at 3, 6, 9 and 12 weeks after emergence. The choice of these three AMF was based on previous studies in which their effectiveness in increasing soybean growth, as well as in alleviating the toxicity caused by Mn excess was verified (Cardoso, 1985).

The fertilization of the clayey soil was based on its chemical analysis (Table 1). There was no need for liming or $\mathrm{K}$ and $\mathrm{S}$ supplement. Biological fixation was responsable for $\mathrm{N}$ supply by inoculating the plantlets at emergence with $4 \mathrm{~mL}$ of a cell suspension (c.a. $1 \times 10^{7}$ $\mathrm{mL}^{-1}$ ) of the strains SEMIA 587 and SEMIA 5019 of Bradyrhizobium elkanii. Phosphorus was added according to the results obtained by Nogueira \& Cardoso (2000), aiming to favour the mycotrophic condition, by giving 51 $\mathrm{mg}$ of $\mathrm{P}$ per pot as ground $(<0.75 \mathrm{~mm})$ triple superphosphate. Boron $\left(0.48 \mathrm{mg}\right.$ as $\mathrm{H}_{3} \mathrm{BO}_{3}$ per pot) and $\mathrm{Mo}(0.15$ $\mathrm{mg}$ as $\mathrm{Na}_{2} \mathrm{MoO}_{4} \cdot 2 \mathrm{H}_{2} \mathrm{O}$ per pot) were furnished in a nutrient solution.

Liming and fertilization of the sandy soil were performed with the objective of having conditions similar to those of the clayey soil in relation to nutrient availability. The soil was limed to reach a cation saturation level (V\%) of $87 \%$, the same observed in the clayey soil,

Table 1 - Chemical characteristics of the soils utilized in the experiment before (B) and after (A) autoclaving. Sandy $=$ Typic Quartzipsamment; Clayey $=$ Typic Rhodudalf.

\begin{tabular}{|c|c|c|c|c|c|c|c|c|c|c|c|c|c|c|}
\hline \multicolumn{2}{|l|}{ Sample } & \multirow[t]{2}{*}{$\begin{array}{c}\mathrm{pH} \\
\mathrm{CaCl}_{2}\end{array}$} & M.O. & $\mathrm{S}$ & $\mathrm{S}-\mathrm{SO}_{4}$ & $\mathrm{~K}^{+}$ & $\mathrm{Ca}^{2+}$ & $\mathrm{Mg}^{2+}$ & $\mathrm{Al}^{3+}$ & $\mathrm{H}+\mathrm{Al}$ & SB & $\mathrm{T}$ & V & $\mathrm{m}$ \\
\hline & & & $\mathrm{g} \mathrm{dm}^{-3}$ & \multicolumn{2}{|c|}{$---\mathrm{mg} \mathrm{dm}^{-3}-\ldots$} & \multicolumn{5}{|c|}{ mmol $\mathrm{dm}^{-3}$} & \multicolumn{2}{|c|}{ 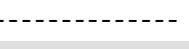 } & \multicolumn{2}{|c|}{$---\%--$} \\
\hline \multirow[t]{2}{*}{ Sandy } & B & 3.9 & 14 & 2 & 8 & 0.5 & 3 & 1 & 9 & 47 & 4.5 & 52 & 9 & 67 \\
\hline & A & 3.8 & 14 & 3 & 10 & 1.1 & 5 & 3 & 8 & 38 & 9.1 & 47 & 19 & 47 \\
\hline \multirow[t]{5}{*}{ Clayey } & $\mathrm{B}$ & 5.5 & 28 & 14 & 11 & 5.8 & 48 & 19 & 0 & 25 & 73.8 & 98 & 74 & 0 \\
\hline & A & 6.2 & 29 & 16 & 14 & 8.0 & 82 & 27 & 0 & 18 & 117 & 135 & 87 & 0 \\
\hline & & & \multicolumn{12}{|c|}{ micronutrients } \\
\hline & & & \multicolumn{2}{|c|}{ B } & \multicolumn{2}{|c|}{$\mathrm{Cu}$} & \multicolumn{2}{|c|}{$\mathrm{Fe}$} & \multicolumn{2}{|c|}{$\mathrm{Mn}$} & \multicolumn{2}{|c|}{$\mathrm{Zn}$} & & \\
\hline & & & \multicolumn{10}{|c|}{ mg dm ${ }^{3}-1$} & & \\
\hline \multirow[t]{2}{*}{ Sandy } & B & & \multicolumn{2}{|c|}{0.40} & \multicolumn{2}{|c|}{0.5} & \multicolumn{2}{|c|}{75.6} & \multicolumn{2}{|c|}{3.6} & \multicolumn{2}{|c|}{1.1} & & \\
\hline & A & & \multicolumn{2}{|c|}{0.21} & \multicolumn{2}{|c|}{0.3} & \multicolumn{2}{|c|}{124.0} & \multicolumn{2}{|c|}{9.8} & \multicolumn{2}{|c|}{0.9} & & \\
\hline \multirow[t]{2}{*}{ Clayey } & $\mathrm{B}$ & & \multicolumn{2}{|c|}{0.70} & \multicolumn{2}{|c|}{7.9} & \multicolumn{2}{|c|}{10.8} & \multicolumn{2}{|c|}{35.8} & \multicolumn{2}{|c|}{3.5} & & \\
\hline & A & & & 44 & & & & .4 & & 5.0 & & 5.1 & & \\
\hline
\end{tabular}


by adding $3.7 \mathrm{~g}$ of dolomitic lime per pot $(\mathrm{CaO} 42 \%$, $\mathrm{MgO} 25 \%$ ). Phosphorus was also added as ground triple superphosphate at a rate of $83.25 \mathrm{mg} \mathrm{P}$ per pot. Potassium and $\mathrm{S}$ were given at rates of $1.67 \mathrm{~g}$ of $\mathrm{KCl}$ and 65 $\mathrm{mg}$ of $\mathrm{CaSO}_{4} \cdot 2 \mathrm{H}_{2} \mathrm{O}$ per pot, respectively. Boron $(1.17 \mathrm{mg}$ as $\left.\mathrm{H}_{3} \mathrm{BO}_{3}\right), \mathrm{Cu}\left(1.5 \mathrm{mg}\right.$ as $\left.\mathrm{CuSO}_{4} .5 \mathrm{H}_{2} \mathrm{O}\right), \mathrm{Zn}(0.9 \mathrm{mg}$ as $\left.\mathrm{ZnSO}_{4} .7 \mathrm{H}_{2} \mathrm{O}\right)$ and $\mathrm{Mo}\left(0.15 \mathrm{mg}\right.$ as $\left.\mathrm{Na}_{2} \mathrm{MoO}_{4} \cdot 2 \mathrm{H}_{2} \mathrm{O}\right)$ were also added as nutrient solution. Iron and $\mathrm{Mn}$ were not added to both soils.

The inoculation of each AMF species was made with a spore suspension, extracted by wet sieving (Gerdemann \& Nicolson, 1963) from a soil cultivated with Brachiaria decumbens. About 240 spores were added per pot and incorporated into the $5 \mathrm{~cm}$ uppermost layer. All pots received $5 \mathrm{~mL}$ of a filtrate obtained by shaking $100 \mathrm{~g}$ of soil with $1.5 \mathrm{~L}$ of distilled water. The suspension was filtered through several sieves, the last one with $45 \mathrm{~mm}$ mesh. The objective of this procedure was to reestablish the original microbial community of the soils in all treatments, except for AMF propagules.

Five seeds of the soybean cultivar IAC- 8 were planted per pot after disinfection with a $25 \% \mathrm{NaClO}$ commercial solution for 5minutes, and rinsing with distilled water. One week after emergence, plantlets were thinned to one per pot. Plants were watered daily with distilled water.

At each harvesting period, 48 pots were harvested. Shoots were cut, washed in a sequence of distilled water, $0.01 \mathrm{~mol} \mathrm{~L}^{-1} \mathrm{HCl}$ solution, and deionized water and dried at $60^{\circ} \mathrm{C}$ until reaching constant weight, to obtain the shoot dry weight (SDW). Soil was removed from roots, then washed in tap water and the same sequence described above was followed to obtain the root dry weight (RDW). Root samples were clarified and stained (Phillips \& Hayman, 1970) for the evaluation of percent root colonization by AMF by means of a squared counting plate (Giovanneti \& Mosse, 1980).

Shoots and roots were ground in a 60 mesh sieve mill and digested with nitric-perchloric acid solution to determine the percentage of $\mathrm{P}$ and $\mathrm{Mn}$ in plant tissues. Phosphorus was determined by metavanadate colorimetry and $\mathrm{Mn}$ by atomic absorption spectrophotometry. There was not enough material for nutrient analysis in the roots.

A soil sample was stored at $5^{\circ} \mathrm{C}$ to estimate the total external mycelium length (TEM), according to Sylvia (1992), modified by Melloni \& Cardoso (1999). These determinations were performed in duplicate, and the mean was used for calculations. To assure the maximum recovery of external mycelium from both soils, $50 \mathrm{~mL}$ of a dispersing solution of sodium pyrophosphate $\left(20 \mathrm{~g} \mathrm{~L}^{-1}\right)$ were added to the samples, incubating them for 40 minutes before extraction. Another soil sample was air dried, passed through $2 \mathrm{~mm}$ sieves and analyzed for available $\mathrm{Mn}$, extracted by Mehlich-I solution $(\mathrm{HCl} 0.05 \mathrm{~mol}$ $\mathrm{L}^{-1}+\mathrm{H}_{2} \mathrm{SO}_{4} 0.05 \mathrm{~mol} \mathrm{~L}^{-1}, 25: 2,5$, shaken for 15 minutes and filtered through filter paper Whatman 42). The extract was evaluated in a Perkin-Elmer atomic absorption spetrophotometer model 560.

Results were statistically analyzed for each harvesting time as a $4 \times 2$ factorial by the statistical software The Statistical Analysis System $\left(\mathrm{SAS}^{\circledR}\right)(\mathrm{SAS}, 1991)$, employing the $t$ test at $P<0.05$. Data for percent root colonization were transformed to $(\mathrm{x}+0.5)^{1 / 2}$ before analysis. The mycorrhizal effectiveness was calculated according to Lambais \& Cardoso (1990), by using the total plant dry weight (SDW + RDW).

\section{RESULTS}

Manganese availability in the soil increased after autoclaving to eliminate native AMF. This increase was about ten times in the clayey soil and almost three times in the sandy soil (Table 1).

SDW and RDW (Table 2) were influenced more expressively by mycorrhizal treatments at the 12 weeks harvest. In the sandy soil there was no difference with regard to SDW between the treatments with $G$. etunicatum and $G$. intraradices. The AMF effect on RDW was seen only at 12 weeks, especially with G. etunicatum and $G$. intraradices, when compared to control plants and those with G. macrocarpum. In the clayey soil, however, G. etunicatum promoted a greater plant growth, while plants with $G$. macrocarpum had a SDW equivalent to the non-mycorrhizal control, and they presented Mn toxicity symptoms as described by Foy et al. (1978).

Generally, for the sandy soil, concentrations of $\mathrm{P}$ were greater in mycorrhizal plants in relation to the control, both in shoots and roots (Figure 1). In plants inoculated with G. macrocarpum, grown in the clayey soil, concentrations of $\mathrm{P}$ in the tissues were, in general, the same as those of the control plants. On the other hand, plants with G. etunicatum and $G$. intraradices presented greater P concentrations in both shoots and roots. The Mn concentrations in plants grown in the sandy soil, either in shoots, or in roots (Figure 2), were greater than in the control plants. In the sandy soil, plants did not present Mn toxicity symptoms at any harvesting period. Conversely, mycorrhizal plants grown in the clayey soil, in general, presented greater Mn concentrations, mainly when inoculated with G. macrocarpum. This caused Mn toxicity symptoms, which probably contributed to reduce plant growth (Table 2). At 12 weeks of age, $\mathrm{Mn}$ concentrations in shoots and roots of plants with $G$. macrocarpum were 1300 and $3400 \mathrm{mg} \mathrm{kg}^{-1}$, respectively, while in the other treatments, Mn concentration did not surpass $700 \mathrm{mg} \mathrm{kg}^{-1}$ in the shoots and $600 \mathrm{mg} \mathrm{kg}^{-1}$ in the roots. Interestingly, 3- and 6-week old plants with G. etunicatum presented the highest Mn concentration in the shoots (about $700 \mathrm{mg} \mathrm{kg}^{-1}$ ), which coincided with the lowest values of SDW and RDW at 6 weeks (Table 2) and the appearance of Mn toxicity symptoms in leaves. 
Table 2 - Shoot (SDW) and root (RDW) dry weights of soybean plants, every three weeks, cultivated in a clayey and a sandy soil, with or without (control) arbuscular mycorrhizal fungi. Same letters at the same harvesting period and soil do not differ $(t$ test at $P<0.05)$.

\begin{tabular}{|c|c|c|c|c|c|c|c|c|}
\hline \multirow{3}{*}{$\mathrm{AMF}$} & \multicolumn{8}{|c|}{ WEEKS } \\
\hline & \multicolumn{2}{|c|}{3} & \multicolumn{2}{|c|}{6} & \multicolumn{2}{|c|}{9} & \multicolumn{2}{|c|}{12} \\
\hline & SDW & RDW & SDW & RDW & SDW & RDW & SDW & RDW \\
\hline & $\cdots$ & & 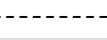 & $-\cdots$ & 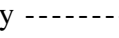 & & & -- \\
\hline Control & $0.40 \mathrm{a}$ & $0.12 \mathrm{a}$ & $2.08 \mathrm{a}$ & $0.53 \mathrm{a}$ & $6.98 \mathrm{~b}$ & $1.38 \mathrm{a}$ & $13.16 \mathrm{c}$ & $2.68 \mathrm{~b}$ \\
\hline G. intraradices & $0.50 \mathrm{a}$ & $0.15 \mathrm{a}$ & $2.71 \mathrm{a}$ & $0.68 \mathrm{a}$ & $9.63 \mathrm{a}$ & $1.66 \mathrm{a}$ & $26.50 \mathrm{a}$ & $4.81 \mathrm{a}$ \\
\hline G. etunicatum & $0.52 \mathrm{a}$ & $0.15 \mathrm{a}$ & $2.60 \mathrm{a}$ & $0.54 \mathrm{a}$ & $10.43 \mathrm{a}$ & $1.62 \mathrm{a}$ & $25.32 \mathrm{a}$ & $4.36 \mathrm{a}$ \\
\hline \multirow[t]{2}{*}{ G. macrocarpum } & $0.35 \mathrm{a}$ & $0.09 \mathrm{a}$ & $2.52 \mathrm{a}$ & $0.57 \mathrm{a}$ & $8.75 \mathrm{ab}$ & $1.62 \mathrm{a}$ & $18.20 \mathrm{~b}$ & $3.29 \mathrm{~b}$ \\
\hline & (n........ & (n-..- & (n-n & --.--.-- & еу -.-.-. & - & - & (n-n \\
\hline Control & $0.65 \mathrm{a}$ & $0.27 \mathrm{a}$ & $2.42 \mathrm{~b}$ & $0.88 \mathrm{a}$ & $6.80 \mathrm{~b}$ & $1.84 \mathrm{~b}$ & $13.32 \mathrm{bc}$ & $3.75 \mathrm{~b}$ \\
\hline G.intraradices & $0.70 \mathrm{a}$ & $0.31 \mathrm{a}$ & $3.44 \mathrm{a}$ & $0.92 \mathrm{a}$ & $9.30 \mathrm{a}$ & $2.00 \mathrm{ab}$ & $16.83 \mathrm{~b}$ & $3.42 \mathrm{~b}$ \\
\hline G.etunicatum & $0.64 \mathrm{a}$ & $0.23 \mathrm{a}$ & $2.20 \mathrm{~b}$ & $0.67 \mathrm{a}$ & $11.18 \mathrm{a}$ & $2.29 \mathrm{a}$ & $21.5 \mathrm{a}$ & $4.69 \mathrm{a}$ \\
\hline G.macrocarpum & $0.70 \mathrm{a}$ & $0.29 \mathrm{a}$ & $2.40 \mathrm{~b}$ & $0.73 \mathrm{a}$ & $4.78 \mathrm{~b}$ & $1.08 \mathrm{c}$ & $9.98 \mathrm{c}$ & $2.18 \mathrm{c}$ \\
\hline
\end{tabular}

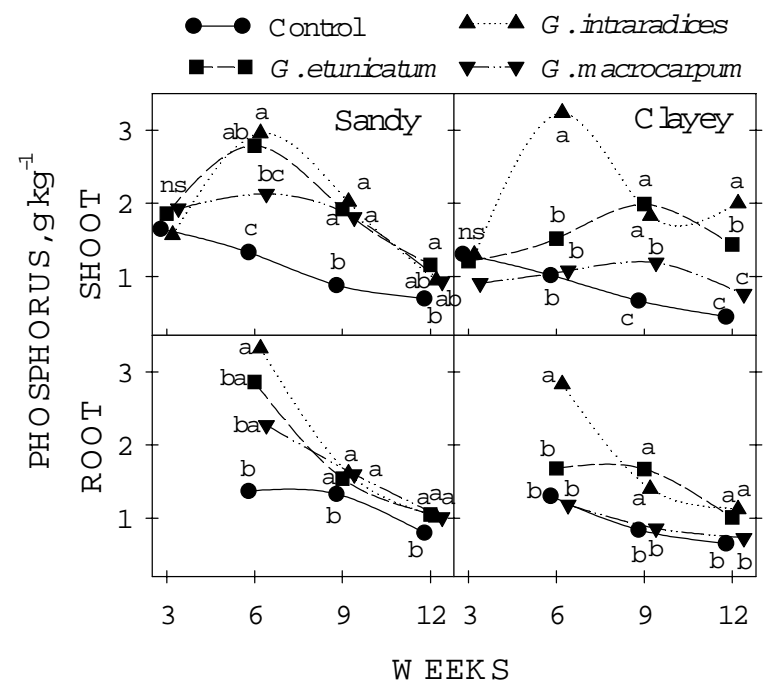

Figure 1 - $\mathrm{P}$ concentration, every three weeks, in shoot and root of soybean plants, cultivated in a clayey and a sandy soil, with or without (control) arbuscular mycorrhizal fungi. Same letters at the same harvesting period and soil do not differ $(t$ test at $P<0.05)$; n.s. $=$ non-significant.

Total external mycelium (TEM) in the soil from mycorrhizal treatments was, in general, greater than in the soil with control plants, except for G. macrocarpum in the clayey soil (Figure 3). The average values of TEM found in the clayey soil were higher than in the sandy soil. Root colonization reached $70 \%$ at 9 weeks in the sandy soil (Figure 3 ). In the clayey soil, root colonization also reached this value in treatments with $G$. intraradices and $G$. etunicatum, but G. macrocarpum presented the lowest levels of root colonization, about $12 \%$ at 9 weeks. In all mycorrhizal treatments, the greatest level of root colonization occurred at 9 weeks, followed by a decrease at 12 weeks.

The concentration of available manganese was higher in the clayey soil (Figure 4). In the sandy soil, Mn concentration varied from 5 to $8 \mathrm{mg} \mathrm{dm}^{-3}$ and there was

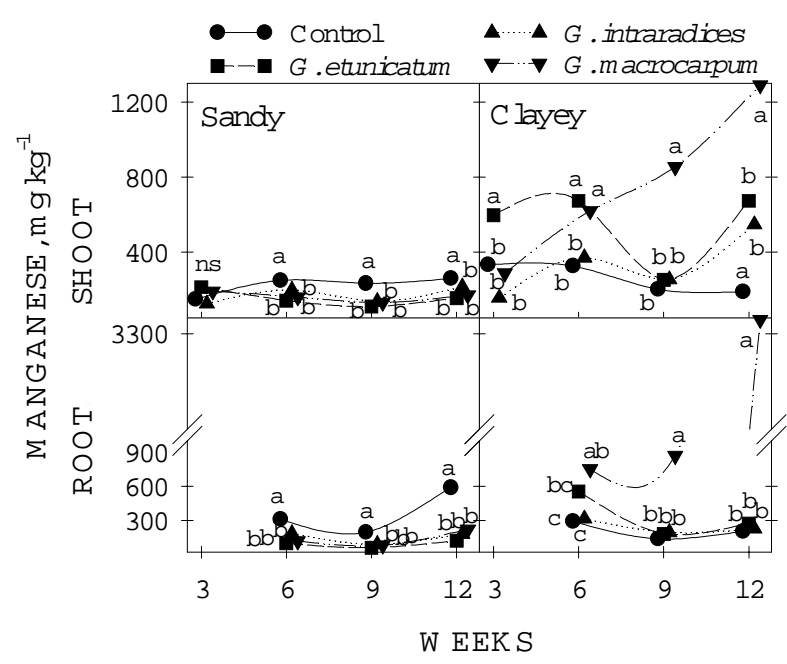

Figure 2 - Mn concentration, every three weeks, in the shoot and root of soybean plants, cultivated in a clayey and a sandy soil, with or without (control) arbuscular mycorrhizal fungi. Same letters at the same harvesting period and soil do not differ $(t$ test at $P<0.05)$; n.s. = non-significant.

no effect of the mycorrhizal treatments. In the clayey soil, however, Mn availability varied from 84 to $414 \mathrm{mg} \mathrm{dm}^{-3}$ and increased for the mycorrhizal treatments, especially with G. macrocarpum.

All AMF species in the sandy soil resulted in an increased host growth as compared to control plants, except at three weeks, when G. macrocarpum decreased plant growth (Figure 5). In the clayey soil, plants with $G$. etunicatum presented a slight negative effect at 3 and 6 weeks, but this was the most effective treatment at the other harvesting periods. G. macrocarpum was the less effective AMF, resulting, at 9 and 12 weeks, in about $30 \%$ less biomass of the host plant in relation to the control plants. In both soils, the effect of the endophytes on plant development increased with plant age. 


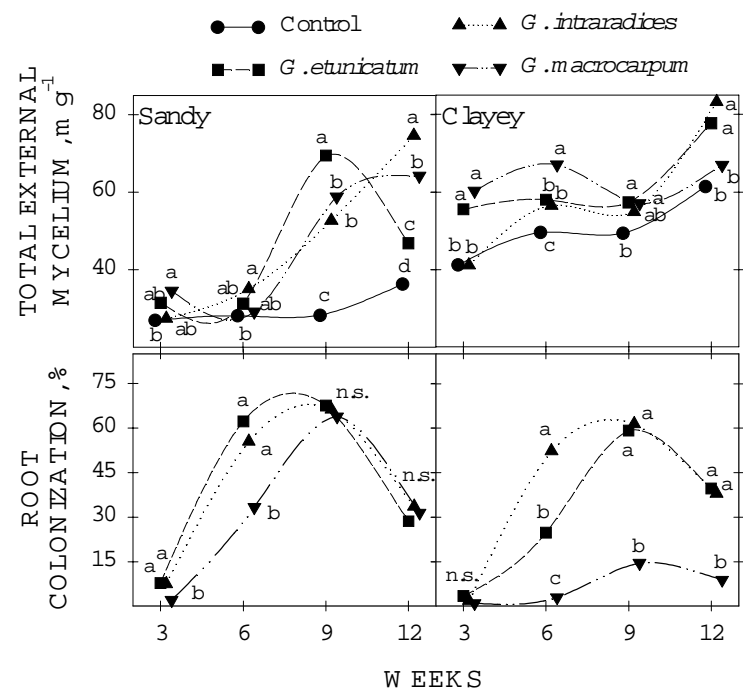

Figure 3 - Total external mycelium length and percent root colonization of soybean plants colonized by arbuscular mycorrhizal fungi, every three weeks, in the shoot and root of soybean plants, cultivated in a clayey and a sandy soil, with or without (control) mycorrhizal fungi. Same letters at the same harvesting period and soil do not differ $(t$ test at $P<0.05)$; n.s. $=$ non-significant.

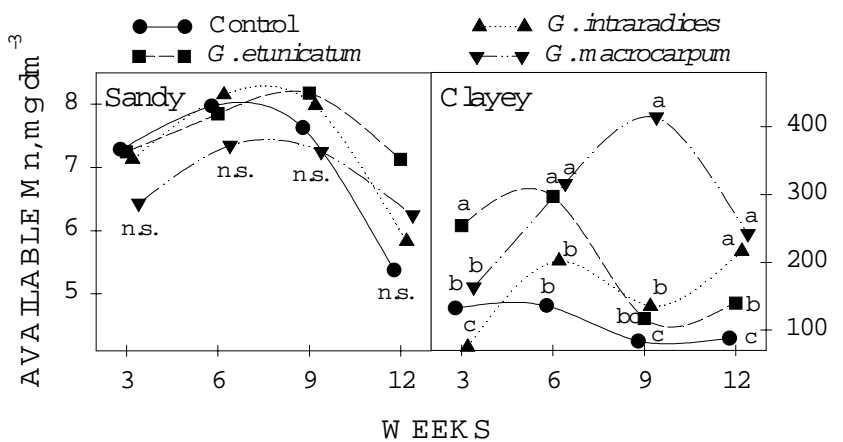

Figure 4 - Available manganese, every three weeks, in a clayey and a sandy soil, cultivated with soybean, with or without (control) arbuscular mycorrhizal fungi. Same letters at the same harvesting period and soil do not differ ( $t$ test at $P<0.05) ;$ n.s. $=$ non-significant.

\section{DISCUSSION}

The finding that plants associated with $G$. macrocarpum in the clayey soil presented more Mn toxicity symptoms and lower growth was surprising, since this behavior was expected to occur in the control plants. In previous experiments, plants inoculated with $G$. macrocarpum, but not the same isolate, presented lower Mn concentration and suppression of Mn toxicity symptoms (Cardoso, 1985). The enhancement or alleviation of Mn toxicity in mycorrhizal plants is not exclusively attributed to the AMF species, but may be the result of several interactions attributed to changes in host physiology, with reflections on the microbial community in the

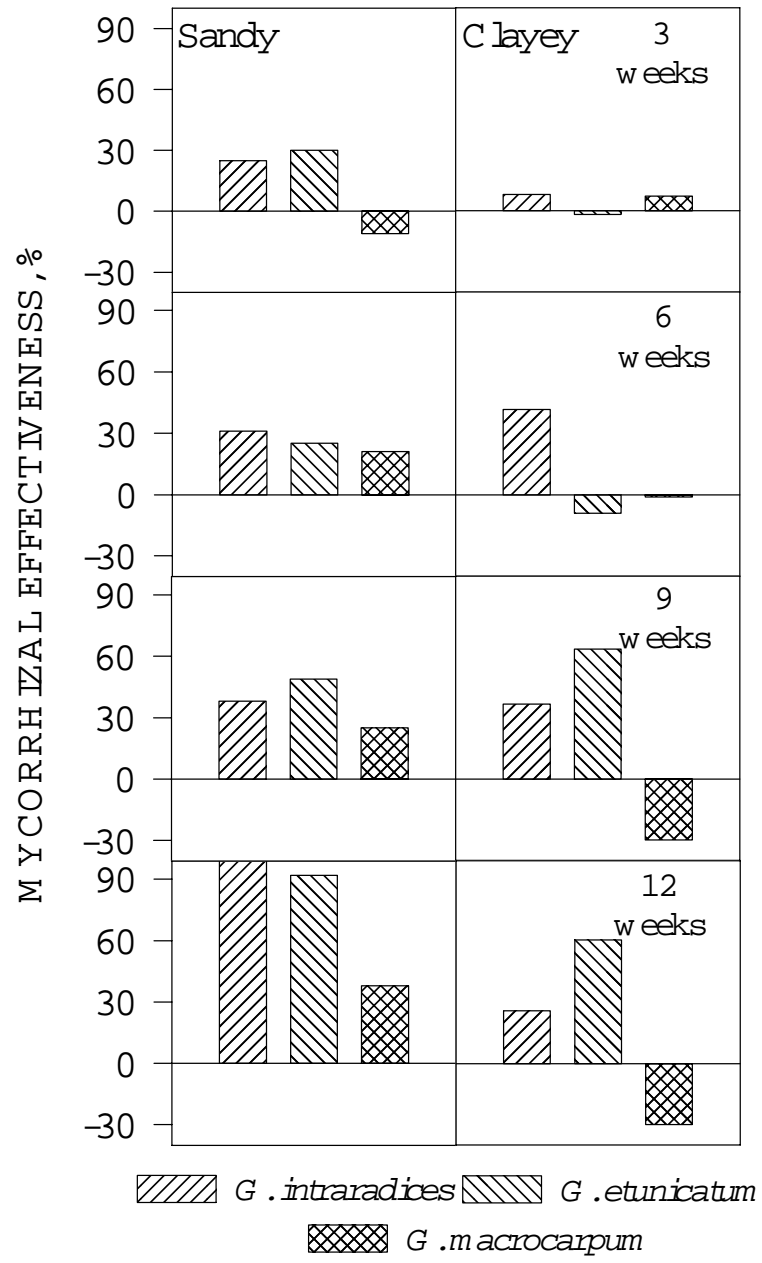

Figure 5 - Arbuscular mycorrhizal fungi effectiveness on soybean plant growth in relation to the non-mycorrhizal control, every three weeks, in a clayey and a sandy soil.

mycorrhizosphere (Filion et al., 1999) and on the biological processes of Mn oxidation (Nealson et al., 1988) and reduction (Kothari et al., 1991). This hypothesis is reinforced by the increase of Mn availability in the clayey soil with AMF inoculated plants. In this case, the increase of Mn availability resulted in the increase of Mn concentration in the plant. Nevertheless, mycorrhizal plants associated with G. etunicatum and G. intraradices also presented higher $\mathrm{P}$ concentrations in the tissues, in spite of their greater biomass. The higher $\mathrm{P}$ concentration in these plants may have enabled better conditions to support the higher Mn concentration in the tissues, suppressing the Mn toxicity symptoms in these cases. Bethlenfalvay \& Franson (1989) observed that, although mycorrhizal plants presented greater Mn concentrations, there were no toxicity symptoms. This might have occurred because of an increase of internal tolerance to Mn (Foy et al., 1978) by plants better fed with P. One of the tolerance mechanisms may be related to a precipitation reaction between $\mathrm{Mn}^{2+}$ and phosphate anions inside the plants, reducing 
$\mathrm{Mn}^{2+}$ activity and, consequently, its adverse effects (Murphy et al., 1981). Habte \& Soedarjo (1996) verified the formation of low solubility products between $\mathrm{Mn}$ and $\mathrm{P}$ in the soil, resulting in $\mathrm{Mn}_{3}\left(\mathrm{PO}_{4}\right)_{2}$. There is no evidence that these reactions did also occur inside the plant in this experiment, but it is a plausible hypothesis. The value for the concentration of $\mathrm{Mn}$ in the plant tissue does not inform about the real activity of $\mathrm{Mn}^{2+}$ ions. One portion of the total Mn could be perhaps precipitated by reactions with phosphate ions, but because of the use of the nitric-perchloric digestion process, all Mn could have been solubilized and quantified. Electron microscopy with X-ray microanalysis might give a better idea about the microdistribution of these possible precipitates inside plant cells (Memon et al., 1981). The lower Mn concentration found in the mycorrhizal plants in the sandy soil probably occurred because of a dilution effect caused by a better growth, because the decrease in $\mathrm{Mn}$ concentration was proportional to the plant biomass increase.

The negative effect of G. macrocarpum in plants grown in clayey soil may be related to certain characteristics of the endophyte. Lower TEM production and the lowest root colonization rates may have been the factors responsible for the lower plant growth, and that indicates the lack of adaptation of this AMF species to that soil. Nogueira and Cardoso (2000) also observed this behavior for other AMF species when associated to soybean, with negative effects on mycorrhizal effectiveness. Microbial interactions may affect mycorrhization and also plant growth when bacteria antagonistic to the AMF become dominant in the rhizosphere (Andrade et al., 1995). Independently of the real cause, the AMF acted as a C sink for the host plant (Bethlenfalvay et al., 1982a).

The increase of Mn availability in the soil after autoclaving is attributed to the thermal breakage of organic chelators, one of the main factors that regulate $\mathrm{Mn}$ availability. Miyazawa et al. (1993) observed that Mn availability decreased with the incubation time, as a result of microbial synthesis of new chelators, but this is also influenced by the activity of Mn oxidizers (Nealson et al., 1988) and Mn reducers (Kothari et al., 1991). In the sandy soil, there was a general decrease of Mn availability with time. In the treatments with AMF in the clayey soil, there was an increase of Mn availability. It is not possible to state definitely whether or not the increase of Mn availability, especially in the treatment with G. macrocarpum, can be attributed to changes in the balance between Mn oxidizers or reducers in the rhizosphere as a result of quantitative or qualitative changes in the root exudates resulting from AMF interactions (Ames et al., 1984) or if it was a direct effect of root exudates, such as organic acids or reducing compounds, modulated by the presence of mycorrhiza (Habte \& Soedarjo, 1996).
A decrease in root colonization was observed from 9 to 12 weeks, and this may have resulted from an extra $\mathrm{C}$ sink related to the pod formation. Possibly root colonization was restricted by the limitation of energetic sources for growth and maintenance of the AMF. In addition, there was active root growth up to 12 weeks, causing "dilution" of the root colonization rate observed at 9 weeks. This behavior probably would not occur if root colonization results were expressed as absolute values of colonized root length, instead of relative values as root colonization percentage (Allen, 2001).

Variations observed in the mycorrhizal effectiveness at different harvesting periods show that results obtained at early plant stages are different from those obtained at late stages. For example, considering the evaluation at 6 weeks in the clayey soil, G. etunicatum was ineffective and $G$. macrocarpum had no effect on the plants. Nevertheless, at 12 weeks, the inverse was observed: plants with $G$. etunicatum presented better growth, while plants with G. macrocarpum presented growth reduction in relation to the control. These observations indicate the importance of evaluating plants after they have had enough time to complete mycorrhizal symbiosis establishment and to express the beneficial or, eventually, adverse effects on plant growth.

\section{CONCLUSIONS}

Mycorrhizal effectiveness varied from beneficial to adverse or indifferent according to the AMF, soil type and stage of plant development. Mycorrhiza alters $\mathrm{Mn}$ availability in the soil, and this affects the Mn concentration in the plants. In the ineffective interaction, mycorrhiza may increase the expression of Mn toxicity symptoms in the host plant. In the effective interaction, in spite of increased $\mathrm{Mn}$ availability in the soil and increased $\mathrm{Mn}$ concentration in plants, no Mn toxicity symptoms were detected in the plants.

\section{ACKNOWLEDGMENTS}

To Denise de Lourdes Colombo Mescolotti and Luís Fernando Baldesin for their assistance during the installation, conduction and analysis of the experiments.

\section{REFERENCES}

ABBOTT, L.K.; ROBSON, A.D. Infectivity and effectiveness of vesicular arbuscular mycorrhizal fungi: effect of inoculation type. Australian Journal of Agricultural Research, v.32, p.631-639, 1981.

ALLEN, M.F. Modeling arbuscular mycorrhizal infection: Is \% infection an appropriate variable? Mycorrhiza, v.10, p.255-258, 2001.

AMES, R.N.; REID, C.P.P.; INGHAM, E.R. Rhizosphere bacterial population responses to root colonization by a vesicular-arbuscular mycorrhizal fungus. New Phytologist, v.96, p.555-563, 1984.

ANDRADE, G.; AZCÓN, R.; BETHLENFALVAY, G.J. A rhizobacterium modifies plant and soil responses to the mycorrhizal fungus Glomus mosseae. Applied Soil Ecology, v.2, p.195-202, 1995. 
BETHLENFALVAY, G.J.; BROWN, M.S.; PACOVSKY, R.S. Relationships between host and endophyte development in mycorrhizal soybeans. New Phytologist, v.90, p.537-543, 1982a.

BETHLENFALVAY, G.J.; PACOVSKY, R.S.; BROWN, M.S. et al., Mycotrophic growth and mutualistic development of host plant and fungal endophyte in an endomycorrhizal symbiosis. Plant and Soil, v.68, p.43-54, 1982b.

BETHLENFALVAY, G.J.; FRANSON, R.L. Manganese toxicity alleviated by mycorrhizae in soybean. Journal of Plant Nutrition, v.12, p.953970, 1989.

CARDOSO, E.J.B.N. Efeito de micorriza vesículo-arbuscular e fostatode-rocha na simbiose soja-Rhizobium. Revista Brasileira de Ciência do Solo, v.9, p.125-130, 1985.

FILION, M.; ST-ARNAUD, M.; FORTIN, J.A. Direct interaction between the arbuscular mycorrhizal fungus Glomus intraradices and different rhizosphere microorganisms. New Phytologist, v.141, p.525-533, 1999.

FOY, C.D.; CHANEY, R.L.; WHITE, M.C. The physiology of metal toxicity in plants. Annual Review of Plant Physiology, v.29, p.511-566, 1978.

GERDEMANN, J.W.; NICOLSON, T.H. Spores of mycorryzal Endogone extracted from soil by wet sieving end decanting. Transactions of the British Mycological Society, v.46, p.235-244, 1963.

GIOVANNETI, M.; MOSSE, B. An evaluation of techniques for measuring vesicular arbuscular mycorrhizal infection in roots. New Phytologyst, v.84, p.489-500, 1980.

HABTE, M.; SOEDARJO, M. Response of Acacia mangium to vesiculararbuscular mycorrhizal inoculation, soil $\mathrm{pH}$, and soil $\mathrm{P}$ concentration in an oxisol. Canadian Journal of Botany, v.74, p. 155-161, 1996.

KOTHARI, S.K.; MARSCHNER, H.; RÖMHELD, V. Effect of a vesiculararbuscular mycorrhizal fungus and rhizosphere micro-organisms on manganese reduction in the rhizosphere and manganese concentrations in maize (Zea mays L.). New Phytologist, v.117, p.649-655, 1991.

LAMBAIS, M.R.; CARDOSO, E.J.B.N. Avaliação da germinação de esporos de fungos micorrízicos vesículo-arbusculares e da colonização micorrízica de Stylosanthes guianansis em solo ácido e distrófico. Revista Brasileira de Ciência do Solo, v.12, p.249-255, 1988.
LAMBAIS, M.R.; CARDOSO, E.J.B.N. Response of Stylosanthes guianensis to endomycorrhizal fungi inoculation as affected by lime and phosphorus applications. Plant and Soil, v.129, p.283-289, 1990.

MEDEIROS, C.A.B.; CLARK, R.B.; ELLIS, J.R. Effects of excess manganese on mineral uptake in mycorrhizal sorghum. Journal of Plant Nutrition, v.18, p.201-217, 1995.

MELLONI, R.; CARDOSO, E.J.B.N Quantificação de micélio extrarradicular de fungos micorrízicos arbusculares em plantas cítricas I. Método empregado. Revista Brasileira de Ciência do Solo, v.23, p.53-58, 1999.

MEMON, A.R.; CHINO, M.; HARA, K. et al., Microdistribution of manganese in the leaf tissues of different plant species as revealed by X-ray microanalyzer. Physiologia Plantarum, v.53, p.225-232, 1981.

MIYAZAWA, M.; PAVAN, M.A.; MARTIN-NETO, L. Provável mecanismo de liberação de manganês no solo. Pesquisa Agropecuária Brasileira, v.28, p.725-731, 1993.

MURPHY, L.S.; ELLIS Jr., R.; ADRIANO, D.C. Phosphorus-micronutrient interaction effects on crop production. Journal of Plant Nutrition, v.3, p.593-613, 1981.

NEALSON, K.H.; TEBO, B.M.; ROSSON, R.A. Occurence and mechanisms of microbial oxidation of manganese. Advances in Applied Microbiology, v.33, p.279-318, 1988.

NOGUEIRA, M.A.; CARDOSO, E.J.B.N. Colonização radicular e produção de micélio externo por duas espécies de fungos micorrízicos arbusculares em soja. Revista Brasileira de Ciência do Solo, v.24, p.329-338, 2000.

PHILLIPS, J.M.; HAYMAN, A.S. Improved procedures for clearing roots and staining parasitic and vesicular-arbuscular mycorrhizal fungi for assessment of infection. Transactions of the British Mycological Society, v.55, p.158-161, 1970.

SAS INSTITUTE. Procedure guide for personal computers. Release 6.11. 5.ed. Cary: Statistical Analysis System Institute, 1991.

SYLVIA, D.M. Quantification of external hyphae of vesicular-arbuscular mycorrhizal fungi. Methods in Microbiology, v.24, p.54-65, 1992.

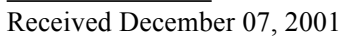

